\title{
Innovation of New Product Development Process: A Case Study of Healthy Drink-Based Product Line in Indonesia's Company
}

\author{
Rahmi Lestari Helmi \\ Research Center for Science Technology and Innovation Policy and Management \\ Indonesian Institute of Sciences (LIPI) \\ A building, 3rd fl. LIPI , Jl.Jend Gatot Subroto no. 10 Jakarta Indonesia
}

\begin{abstract}
The research was financed by National Innovation System Research Incentive, Ministry Research and Technology, Republic of Indonesia (SINAS Ristek)

Abstract

Contemporary and performing organizations are under tremendous pressure to bring new products and to market them quickly. However, the task of new product development requires significant investment and time in addition to making various decisions during the NPD process. The aims of the study is to identify pattern and model of new product development (NPD) process conducted by an Indonesia's local company ("S" company), particularly for healthy drink, "K" products line to meet best practice in NPD. The research was also conducted to determine the factor(s) that promote and hinder innovation culture within the company, which can affect the company's competitiveness. Descriptive analysis of factors and determinants which support and hinder the NPD process are provided using strategic assessment and alignment model. The mapping status of newess level of products or portfolios, level of innovativeness and NPD stages are analysed using a Stage-Gate framework. The result found that the process of innovation and NPD in "S" company strongly associated with personal figure of the CEO/top manager or top-down appraoch. The fact that informal NPD process in "S" company is seemingly spontaneous, natural yet very flexible and highly dependent on CEO's intuition.
\end{abstract}

Keywords: new product development process, Indonesia, healthy drink, innovation

DOI: $10.7176 / \mathrm{EJBM} / 11-24-17$

Publication date: August $31^{\text {st }} 2019$

\section{Introduction}

Company or business organization must be able to adapt in order to survive. Businesses operate with the knowledge that their competitors will inevitably come to the market with a product that changes the basis of competition. The high level of competition is characterized by the increasing number of emerging similar products at the marketplace. Competition among similar bussineses are getting more tremendous so company must allocate adequate resources and strategy to maintain the level of competitiveness. One of most of strategic decision in company to winning the competition is to develop a strategy of new product development and innovation.

Innovation it self, is a very broad concept that can be understood in a variety of ways. One of the more comprehensive definitions is offered by Myers and Marquis (1969 in Trott 2005 ):

Innovation is not a single action but a total process of interrelated sub processes. It is not just the conception of a new idea, nor the invention of a new device, nor the development of a new market. The process is all these things acting in an integrated fashion.

The conception of innovation can be distinguished from invention by suggesting that innovation is concerned with the commercial and practical application of ideas or inventions.

Furthermore, the conception of new ideas is the starting point for innovation. A new idea by itself, while interesting, is neither an invention nor an innovation, it is merely a concept or a thought or collection of thoughts. The process of converting intellectual thoughts into a tangible new artefact (usually a product or process) is an invention (Trott 2005). This is where science and technology usually play a significant role. At this stage inventions need to be combined with hard work by many different people to convert them into products that will improve company performance. To summarise, then, innovation depends on inventions but inventions need to be harnessed to commercial activities before they can contribute to the growth of an organisation. Thus:

Innovation is the management of all the activities involved in the process of idea generation, technology development, manufacturing and marketing of a new (or improved) product or manufacturing process or equipment.

Based on the conception given above, innovation was defined as the application of knowledge. This notion that lies at the heart of all types of innovations (e.g product, process, organization, production, or service innovation) as desribed by Mattews \& Manley (2009). It is noticeable that many studies have suggested that product innovations are soon followed by process innovation in what they describe as an industry innovation cycle. Furthermore, it is common to associate innovation with physical change, but many changes introduced within organisations involve very little physical change. Rather, it is the activities performed by individuals that 
change. A good example of this is the adoption of so-called Japanese management techniques by automobile manufacturers in Europe and the United States (Nonaka \& Takeuchi 1995; Mathew \& Manley, 2009; Lunvall \& Nielsen, 2007).

The NPD process is often described as a sequential linear process consisting of activities from idea generation to product launch (Trott, 2005). Contemporary and performing organizations are under tremendous pressure to bring new products and to market them quickly. However, the task of new product development requires significant investment and time in addition to making various decisions during the NPD process.

Ganguly et al. (2013) states new product development (NPD) is vital for all companies. Previous research indicates that the success of new products is dependent upon how professionally the development process is performed. In particular, the proficiency of NPD activities has a positive effect on product quality. On other hand, NPD is one of the riskiest, yet most important, endevour of the modern corporation.

Studies on accelerated product development may be categorized into four streams of research (Griffin, 2002 in Langerak, 2010). The first category encompasses grounded-theory approaches and small-sample studies conducted to uncover the drivers of product development cycle time. The output of these efforts are numerous factors assumed to be associated with development cycle time, including project strategy features (e.g.,product complexity, strategic intent, level of innovativeness, and technical difficulty), development process characteristics (e.g., formality, stages, and structure), and organizational characteristics (e.g., team use and assignment level, leadership style, size, and innovation level). The second category synthesizes these exploratory findings to develop conceptual models and test the hypothesized influence(s) of accelerated product development on project strategy, and process and organizational characteristics on development time. Other studies have identified a number of organizational actions that firms can take to reduce development cycle time, in particular improving the R\&D-marketing-manufacturing interface by establishing cross-functional teams, and simplifying the organizational structure. The third stream of research comprises studies that investigate the outcomes of development cycle time reduction in terms of development costs, product quality, and project success. The fourth category of research reflects on these divergent empirical results via its employment of (mainly) the survey methodology to examine the moderating effects of contextual factors, such as uncertainty, product innovativeness, new-product strategy, team improvisation, and customer participation.

" $\mathrm{S}$ " company is a well-kown local company industry's leading herbal extracts in Indonesia. The company has implemented international standards in manufacturing activities, which include HACCP ISO 9001: 2008, QS-9000, and OHSAS 18001. K product line, one of healthy product line/brand name, is targeted for export market. K product line export market currently account for 31-40\%, which includes Northern Europe, Asia, Middle East, and Western Europe with total annual sales of the K brand have reached US \$ 10 million-50 million (Helmi, 2015). Although the company have launched more than 100 brands and variants, $\mathrm{K}$ product line is selected as an object of study case. The first consideration is, as energy drink, $\mathrm{K}$ line products are national leading market and categorized as cash cow to company so company have to drive innovation and sustainable new product development in order to maintain its position as market leader. Other consideration is related to business competition. Technically, Competitor will be relatively easier to copy a me-too product formula so there is possibility that competitors may shift current position of company in the market. Helmi (2015) also noted that is as many as 34 product lines or brand name of energy drink are manufactured and distributed nationwide. Market potential of energy drink, or healthy drink is considered a fast moving business. Many national and multinational companies have invested in related product and brand name to seize the market share.

The aims of the study is to identify pattern and model of NPD process conducted by an Indonesia's local company (PT S), mainly for healthy drink $K$ products line to meet best practice in new product development. The research was also conducted to determine the factor(s) that support and hinder innovation culture within the company, which can affect the company's competitiveness. Although most new product may fail before and after launching, an effective and efficient NPD process and resource allocation can minimise the risk of loss and have opportunities to gain profit to cover the loss.

\section{Methodology}

A case study of NPD process in local company ("S" company) is the subject of this research. The NPD analysis focus on " $\mathrm{K}$ " product line, while " $\mathrm{K}$ " is brand name for a product line which consist of several product items or variants. The intention of the study is to map factors and determinants affected the NPD process at PT $S$. The mapping status of newess level of products or portfolios, level of innovativeness and NPD stages are analysed using framework described by Booz-Allen \& Hamilton (Cooper, 2001: Broring et al., 2006).

Kleinschmidt and Cooper (in Cooper, 2001) categorise three simple classes of new products in terms of innovativeness: (1) highly innovative products, namely new-to-the-world products and innovative new product lines to the company, (2) moderately innovative products, consisting of new lines to the firm, with products that are not as innovative (that is, not new,] to the market), and new items in existing products line for firm, (3) low innovativeness products, consisting of all others: modification to existing products, redesigned products to 
achive cost reduction; and repositionings.

Descriptive analysis of factors and determinants which support and hinder the NPD process are provided using strategic assessment and alignment model (Ekstedt, et al.,2005; (Arnzten \&Voransachai, 2008; Gmelin \& Seuring, 2014a).

Primary and secondary data are collected during 2013-2015. A semi structured questionnaire are developed in order to provide primary data. In-depth-interview with marketing manager and R \& D manager in the company are conducted to uncover the NPD process and pattern. Secondary data and information concerning the products and company performance are obtained over the company's annual report.

\section{Result And Discussion}

\subsection{Innovativeness of " $K$ " line Product}

There are a total of 25 product items under the "K" brand as shown in Table 1., Table 2. And Figure 1. Considering the life cycle of the similar food and beverage product, product items/variants which have launched for more 5 years are not considered 'new product', meanwhile 11 out 25 product items categorised as 'new product'. In spite of one item of traditional herb (or jamu) under "K" product line, was not necessarily a new product at present, however, by the first time launched, the herb is categorized as highly innovative product. The company claimed the first four product item also a breakthrough product at that periode. The breakthrough was in the way or method in preparing tradisional herbal medicine or traditional herb ('jamu'). Consumer usually take traditional herb with natural bitter taste. The innovator formulated the traditional herb to reduce the bitterness, without reducing the efficacy of herbal medicine.

Table.1 Summary of new products portfolios derived from the "K" product line

\begin{tabular}{|c|c|c|c|}
\hline $\begin{array}{c}\text { Number of product } \\
\text { items/variants }\end{array}$ & Category & Launched & $\begin{array}{c}\text { Innovativeness and successful/failure in } \\
\text { the market1) }\end{array}$ \\
\hline 4 & $\begin{array}{c}\text { traditional herbal } \\
\text { medicine/traditional herb } \\
\text { (Indonesia: 'jamu') }\end{array}$ & $>5$ years & $\begin{array}{l}\bullet \text { 1 out } 4 \text { is categorized as highly } \\
\text { innovative } \\
1 \text { out } 4 \text { is considered successful in the } \\
\text { marketplace }\end{array}$ \\
\hline 7 & instant traditional herb drink & $>5$ years & -data not available - \\
\hline 1 & food supplement & $>5$ years & -data not available - \\
\hline 2 & healthy drink & $>5$ years & $\begin{array}{l}\bullet 1 \text { out } 2 \text { is categorized as moderately } \\
\text { innovative } \\
1 \text { out 2 is considered successful in the } \\
\text { marketplace }\end{array}$ \\
\hline 11 & healthy drink & $<5$ years & $\begin{array}{l}\text { 1 out 11 product items are categorized as } \\
\text { moderate and 10 out } 11 \text { as low } \\
\text { Product items are considered failure, } \\
\text { successful, very succesful, and quite } \\
\text { successful in the marketplace**) }\end{array}$ \\
\hline
\end{tabular}

Note 1) criteria of successful successful, very succesful, and quite successful in the marketplace determined by the company, which is based on selling point per per year of individual product item.

Among total 4 product items of traditional herbs under " $K$ "-product line, only one considered very successful in the marketplace. The term of 'successful' (including'very successful' and 'quite successful') or 'failure' is depend on number of sales in a certain period (sales data not available). The impact of products innovativeness of new product success is not nearly as straightforward as expected by company while failure rate do not necessarily steady increase (or steadily decrease) with increasing innovativeness.

Furthermore, traditional herb product items were continue to improve and the company released up to 7 variants of instant traditional herb following regular traditional herbs. Unfortunately, in term of market, data indicates successful or failure of the product in the market after launching is not available. The similar explanation applies to the food supplement product items/variants. There was possibility that the product items have failed in the market for some reasons. Thus, It implies to the company's strategic decision whether the product development discontinue or continue. The strategic decision, then highly depend on the market response and sales of individual product item. 
Table 2. Inovativeness category of "K" product line

\begin{tabular}{|c|c|c|}
\hline Product item (code name) & Innovativeness category $^{1}$ & Description of inovativeness \\
\hline $\mathrm{KB}^{2}$ & Highly innovativeness & $\begin{array}{l}\text { a new product that has never existed } \\
\text { in the market and for the company }\end{array}$ \\
\hline $\mathrm{KG}^{2}$ & Moderate innovativeness & $\begin{array}{l}\text { a new product category of " } \mathrm{K} \text { " } \\
\text { product line }\end{array}$ \\
\hline KG2 & Low innovativeness & \multirow{11}{*}{$\begin{array}{l}\text { Flavor and taste improvement from } \\
\text { existing products, repackaging, } \\
\text { modification to ready to drink (RTD) } \\
\text { formula, }\end{array}$} \\
\hline KG3 & Low innovativeness & \\
\hline KG4 & Low innovativeness & \\
\hline KG5 & Low innovativeness & \\
\hline KG6 & Low innovativeness & \\
\hline KG7 & Low innovativeness & \\
\hline KG8 & Low innovativeness & \\
\hline KG9 & Low innovativeness & \\
\hline KG10 & Low innovativeness & \\
\hline KG11 & Low innovativeness & \\
\hline KG12 & Low innovativeness & \\
\hline
\end{tabular}

Note 1) in accordance with Booz-Allen \& Hamilton category (Cooper, 2001), 2) not including new product category which launched for more than 5 years

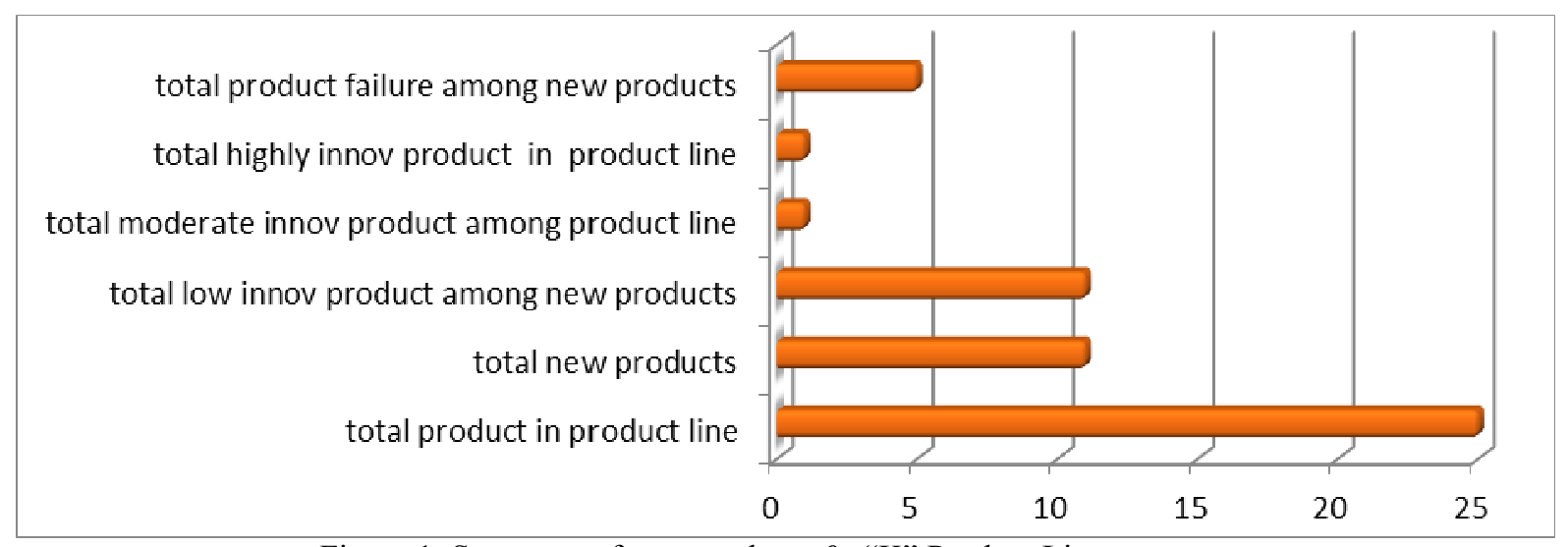

Figure 1 Summary of new products \& "K” Product Line

\subsection{New Product of healty drink}

The next category of product items under " $\mathrm{K}$ " product line is healthy drink/energy drink. The product which as many as 14 product items were considered as moderately innovativeness as described by Kleinschmidt and Cooper (Cooper 2001) . It indicates that the healthy drink or energy drink is new product under "K" product line, following traditional herbs, instant traditional herbs and food supplement. The term 'moderate' indicates that the product derived from existing " $\mathrm{K}$ " product line, or the same product line.

NPD process in "S" company is initiated from 1980s so everage rate of new product launched per year is 2 (two). The sales of KG 1-KG12 (see table 1 and table 2) accounted for $85 \%$ of the "K" product line sales, and contributing $40 \%$ of sales of the company (Helmi, et al, 2015).

According to Figure 1, among a total 25 product items derived from "K" product line, 5 product items are confirmed failure in the market place. However, the failure rate (proportion of number of new product failure (s) and total number of product items) is relatively low. Unfortunately, no detailed information of company's portfolios has developed in last five year so the exact failure rate can not be determined.

Some studies showed, at least three main causes of new product failure. The highest percentage of failure may caused by inadequate market analysis and effort. Insufficient of faulty marketing research is what managers cite most frequenty as the number one product failure. Brethauer (2002) and Cooper (2001) found that a lack of thoroughness in identifying real needs in the marketplace, or in spotting early signs of competitors girding up to take the offensive. The failure also triggered by assuming "the product would sell it self" and simply failed to back the product's launch with suffient marketing, selling and promotional resources.

The second most common cause of new product failure is technical problem. Difficulties in trying to convert from laboratory or pilot-plant scale to full-scale production are common, while manufacturing glitches and product quality problem frequently arise (Felekoglu et al., 2013; Ganguly, et al, 2013). In many cases, it's a failure to conduct the earlier phase more thoroughly-technical research, design, engineering-before moving to the 
commercialization phase. Other reason is, lack of understanding of customer's requirement. The third cause of product failure is bad timing. Timing issues is a key reason for failure. The penalties of moving too slowly, or too fast, stem from, not only technical issues, but also from unorganized planning, executing and evaluating.

Gmelin \& Seuring (2014b) also stated that at least 4 (four) success factors in achieving sustainable new product development; (1) cross-functional work, (2) top-management support, (3) market planning, and (4) formalized process. Numerous new products failures result from not moving quickly enough, given a limited window of opportunity. In case of "S company", although most of the product item of "KG2-KG12" has the same basic formula, not all the product items successful in the market. The case study uncovered the company have set a low innovative strategy in "K" product line by following works such as flavor and taste improvement from existing products, repackaging, and modification to ready to drink (RTD) formula. The strategy have been taken to accelerate the NPD process, and minimalizing the failure rate. The NPD strategy was taken also to assure a product launch timing. If not, it might be possible of shift in customer preferences during development cycles; while the competitors moves more quickly with a new product and seize the marketshare. In term of technical aspect, the failure of some "K" product items in the product line have indicated that NPD process might not sharpen product differentiation among items so that customers in the market couldn't recognize the items as one product/item. The facts was, beside the low proportion of product failure compared to the success, the market failure of some " $K$ " product items was unevitable, so it was critical process to provide a sufficient market data or consumer preference, which would lead to a preferable product/variant. Even the failure rate was moderately higher than existing items, revenue generated from the success product covered the overall NPD cost of "K" product line

\subsection{Stages of NPD process}

The dynamic NPD in "S" company have been carried out since 1980s, and no formal NPD structure in the company. The NPD process, as part of company strategy to lead the national market, is managed informally. In managing innovation process, a source of new product idea, most frequently generated from key person(s) in the company. Informality of NPD in the company is indicated by several indicators. First, no written documents or SOP or other formalized process dealing with the NPD process which can be used as guidance or manual. Second, inspite of the NPD planning usually established a year before, the company's flexibility in NPD projects is relatively high. The third, idea of innovation and NPD in the company, is highly dependent to key person (s).

In order to understand the basic idea of NPD process in "S" company, the following reconstruction (Fig. 2 and Table 3) is developed by adapting the State-Gate system (Cooper, 2001):

\section{The Simple steps to product development $\left({ }^{*}\right)$}
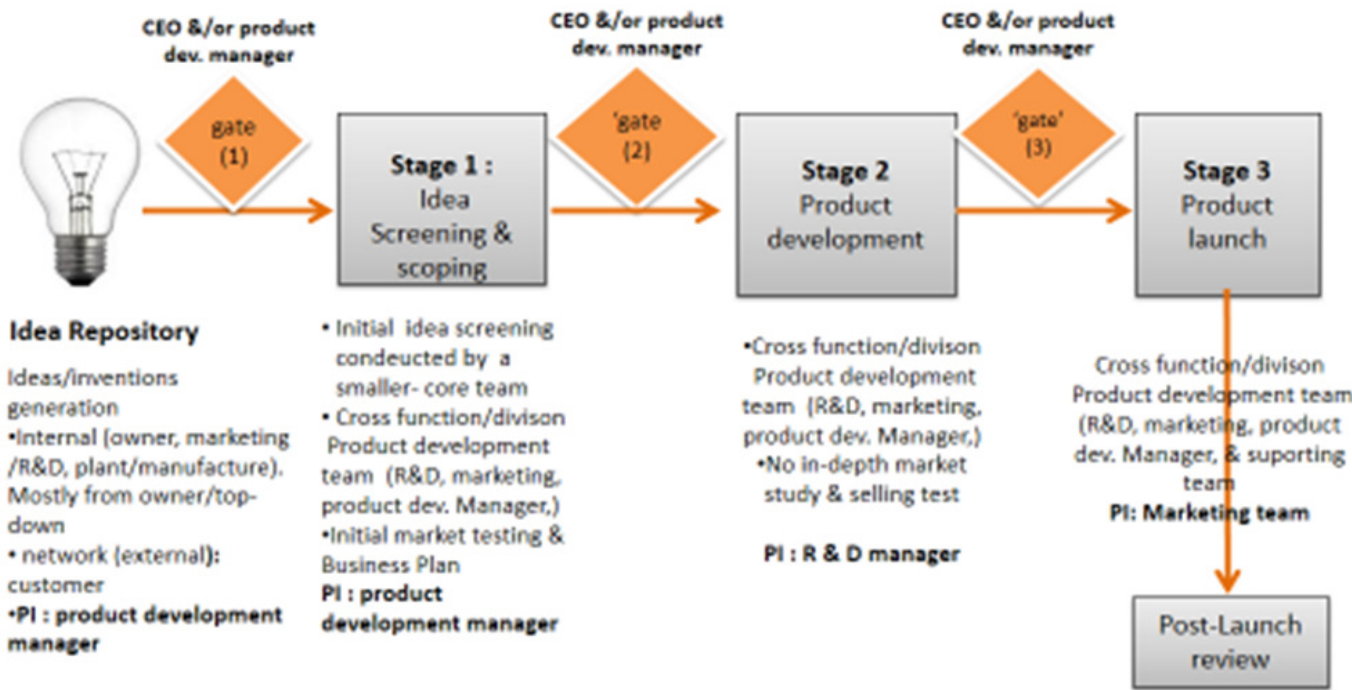

$\left({ }^{*}\right)$ The simple step are reconstructed on New Poduct Development of KG2-KG12 product items

Mostly carried out by marketing \& suporting team to identify 'failure' \& 'success' of new product lounched

PI: Marketing team

Figure 2. The simple steps reconstruction of NPD of KG2-KG12 
Table 3. State-Gate system interpretation of NPD of KG2-KG12

\begin{tabular}{|c|c|c|}
\hline Stage & $\begin{array}{c}\text { Main activity/process of new product } \\
\text { development }\end{array}$ & Constraint /challenging \\
\hline Idea repository & $\begin{array}{l}\text { - Deriving source of ideas/inventions } \\
\text { derived from internal and external } \\
\text { organization } \\
\text { indentifying detailed description on } \\
\text { internal-sourced ideas which generated } \\
\text { from key person in company } \\
\text { (if any) indentifying detailed description on } \\
\text { an external-sourced ideas which generated } \\
\text { from outside company (customers, } \\
\text { suppliers, networks, or scientists from } \\
\text { universities and R\&D organization) } \\
\text { Person in charge (PIC): Product } \\
\text { Development Manager (PDM) }\end{array}$ & $\begin{array}{l}\text { - Highly intervension of key person (s) in } \\
\text { strategic position/top-down ideation } \\
\text { process } \\
\text { - bottom-up idea(s) might not be or less } \\
\text { accommodated } \\
\text { - The NPD planning is too flexible, } \\
\text { spontaneous, and could be changed } \\
\text { from the annual plan }\end{array}$ \\
\hline Gate 1 & Gate keeper: PDM and/or CEO & \\
\hline $\begin{array}{l}\text { Stage 1: } \\
\text { Idea screening } \\
\& \text { selection }\end{array}$ & $\begin{array}{l}\text { - Initial screening to test the idea prior to } \\
\text { NPD process } \\
\text { - An initial idea screening was adjusted } \\
\text { through a smaller team's feedback (the } \\
\text { small team represented division/position of } \\
\text { top management, marketing, R \& D) } \\
\text { - Initial assessment in justifying further NPD } \\
\text { proccss within team (marketing team } \\
\text { provided data from customer feedback and } \\
\text { suppliers) } \\
\text { - Building an initial business case } \\
\text { - 'in-house' testing (technical assessment) } \\
\text { - PIC: Product Development Manager }\end{array}$ & $\begin{array}{l}\text { - adjustment the scoping is highly } \\
\text { dependent on the small team's ability in } \\
\text { data interpreting } \\
\text { - relevant only for low innovative } \\
\text { products, less relevant for moderate and } \\
\text { highly innovative products }\end{array}$ \\
\hline Gate 2 & Gate keeper: PDM and/or CEO & \\
\hline $\begin{array}{l}\text { State } 2 \text { : product } \\
\text { development } \\
\text { stage }\end{array}$ & $\begin{array}{l}\text { - Involving the bigger-cross functional team } \\
\text { in company (marketing, R \& D and } \\
\text { supporting team) } \\
\text { - 'in house' NPD testing involved other } \\
\text { employees (eg. sensory test) } \\
\text { - Technical testing and validating products } \\
\text { were carried out under limited scale } \\
\text { production } \\
\text { - PIC : R \& D Manager }\end{array}$ & $\begin{array}{l}\text { - more technical assessment to obtain } \\
\text { initial prototypes, } \\
\text { - no detailed market study or no market } \\
\text { related-activity test or selling of tests } \\
\text { conducted by the company prior to } \\
\text { launch of the product }\end{array}$ \\
\hline Gate 3 & Gate keeper: (PDM) and/or CEO & \\
\hline $\begin{array}{l}\text { Stage 3: } \\
\text { product launch }\end{array}$ & $\begin{array}{l}\text { - The stage involved a bigger cross functional } \\
\text { team (marketing, R \& D, legal) } \\
\text { - Applying overall process in company : full } \\
\text { production and marketing process } \\
\text { - PIC: Marketing Manager }\end{array}$ & $\begin{array}{l}\text { - highly dependent on the ability to } \\
\text { achieve initial market data/market } \\
\text { testing }\end{array}$ \\
\hline $\begin{array}{ll}\text { Post launch } \\
\text { Review }\end{array}$ & 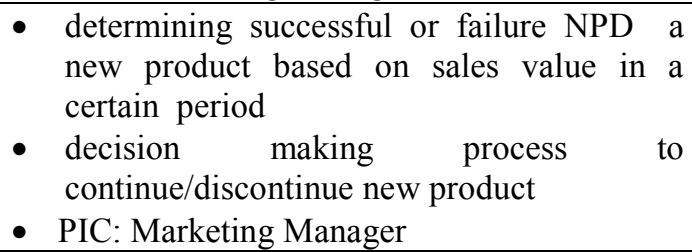 & $\begin{array}{l}\text { - Determining sales periode, marketing } \\
\text { efforts versus inovativeness/newess } \\
\text { level of NPD, the lower the } \\
\text { inovativeness, the shorter the testing } \\
\text { periode }\end{array}$ \\
\hline
\end{tabular}

3.4 Driving force for NPD innovation in organization

"S" company have already have strategy formulation in NPD. The company tends to apply a simplyfied StateGate model in promoting NPD ("K" product line). The simplification of the model implies toward a quick, and profitable innovation process. State-Gate model is a business process for value creation that is designed for 
quick and profitable transformation of company’s best ideas into new products/services (Stosic \&Radul, 2014). Based on the data of the NPD per year, top management aware that the survival strategy of the company depends on product performance. The company realize that product innovation or NPD is not a 'stand alone strategy" must be taken. Although the inovativeness of "K"-product line tends to a low level category, the company have applied a combination of innovation strategies in improving company performance, namely innovation in marketing and promotion. Interestingly, the promotion and marketing launched by the company were through values proposition. Shared value of the company's reflects in its vision, mission and ambition. Philosophy of the values is closely related to the new products themselves, which are rooted from Indonesia's local cultural traditions in dealing with health and prevent illness. The values which wanted to share by the company on medias, mostly promote issues such as 'the pride of being part of Indonesian, nationalism, local wisdom, traditional art and culture, diversity, environtment, peace, humanity, healthy lifestyle, and Indonesia's spectacular panoramas. Representation of the values were also performed by the prominent figure(s) as role models on electronic or printed promotion medias.

Ideally, company generates an organizational culture that nurture the NPD process with high-performance teams, focus on customers and markets, excellent solutions, compliance, discipline, speed and quality. Despite the promotion and marketing innovation strategies have implied to increase much more resources allocation than NPD itself, the company have tendency to foster a dynamic and flexible relationship that is very supportive toward innovation in organiation. The fact is, "S" company has no formal NPD process and guidelines, so the company must formalize the process in order to increase efficient and effective NPD process. It can be concluded that the informal style in the NPD is very spontaneous, flexible, and mostly top-down approach.

The company fostering innovation culture in the organization by involving cross fuctional teams to executing NPD who represent R \& D, marketing, IT, HR, legal, design, promotion and finance. It was also revealed that the key persons (CEO and/or R\&D manager) is also innovator in " $\mathrm{S}$ " company. Even " $\mathrm{S}$ " company is an Indonesia's key player in traditional herb industry, it was managed as family enterprise. As the company growth is geting bigger, the centrality of CEO in NPD process relatively unchanged and strongly dominated the process. Thus, In the context of the NPD process, the CEO plays main role as intrapreneurship and entrepreneurship. According to Pinchot (1995 in Iqbal et al, 2011), at least 8 characteristics of intrapreneurship and entrepreneurship have ability in; (1) combining vision and action, (2) managing risk, (3) coping with mistakes and failures, (4) determining a high internal standard for him/herself, (5) determining clear objectives, (6) placing high priority on performance, (7) seeking the pleasure of the workload, and (8) managing a hybrid company.

In case of " $\mathrm{S}$ " company, the most prominent figure of the CEO is seemingly able to capture the market opportunity through the values creation as described above. It was reflected by the NPD and innovation marketing strategy $\mathrm{He} / \mathrm{she}$ is able to integrate the NPD process in the company and convert the original ideas into something concrete and workable so that it can be realized in a concrete new products. The figure also has a capability to bridge the ideas and inventions generated by knowledge workers become valuable innovation and profit. Invention and ideas that worked in NPD process not limited sourced from the internal organization alone, but can also come from the network and its external sources over the years. The nature of intrapreneurship and entrepreneurship is also further gradually transmitted to other family members (who currently have strategic positions in the company) due to intensive interaction in managing a family business. The companies should make efforts so that the ability of intrapreneurship and entrepreneurship of the figure can be transmitted to other employees.

\subsection{Factors that hinder NPD innovation in organization}

Kohne \& Sawyer (2018) described that the main reason can be attributed failure of NPD innovation process is: communication barriers between functional departments. An organization has to make sure that the regarding departments interact efficiently with each other. Another explanation triggering the failure of the launch is the lack of communication internally: between Chief Investment Officers and Chief Executive Officers, but it also occurs between management and staff. In case of the "S" company, the low failure rate of NPD was faund relatively low to moderate. Our finding was, the most contributor to NPD's ideation orginated from a top-down mechanism so communication barrier among top management level was deminish. However, future NPD process in a long range of " $\mathrm{S}$ " company growth, the company should considered more on implementing a bottom up mechanism. Over-reliance on inividual's idea toward NPD process may lead declining in future NPD performance.

The NPD planning in "S" company is too flexible, spontaneous, and can be changeable so the company should establish more formal structure of NPD in the organization. Too flexibility on NPD process may lead to a 'bad timing' or delay the outcomes. The wider impact of 'bad timing' also lead to a big loss. There must be a balance between flexible and formalized process of NPD (Felekoglu et al., 2013). The company's formal NPD process must be considered as tool to win the competition, while from technology point of view, the 
healthy/energy drink formula is relatively easily imitized by competitor so the company have to emphasis on, not only the NPD innovation it self. It indicate that the growth of healthy drink industry is very promising and influenced by urban life style. According to the Ministry of Industry of Indonesia, recent data was recorded in the third quarter of 2018 the growth of the food and beverage industry reached $8.67 \%$ or exceeded the national economic growth of $5.27 \%$. Over the past year, the food and beverage industry grew $9.23 \%$ per year (Pratama, 2018). Furthermore, its critical point to asses of product life cycle, as part of NPD manajement in order to minimize loss and anticipate 'bad timing' as stated by Gmelin \& Seuring (2014b)

Regarding state gate intepretation of NPD process in "S" company, the problems and pitfalls identified in three points, namely an inadequate market analysis, failure to understand customer need and wants, and insufficient attention to the market place. Cooper (2001) stated that a lack of market orientation is consistently cited as major reason for NPD failure. Simply stated, the company tent to omit many of critical marketing tasks, particularly those in the early phase of project. Activities such as the detailed market study (to determine customer need and to assess likely market acceptance) and test market or trial sell (to test the launch plan and determine market penetration). Considering the existing size of the company, a cross functional team was very limited, while too many NPD projects were conducted. The lack of time, money, and people is the root cause of errors for product performance.

\section{Conclusion}

The study case revealed that the success of "K" product items was on the innovation strategies, which applied an integrated process of NPD, marketing and promoting. The process of NPD innovation in "S" company strongly associated with personal figure of the CEO/top manager who is also an intrapreneur and innovator in the organization. The fact that informal NPD process in " $\mathrm{S}$ " company is seemingly spontaneous, natural yet very flexible and highly dependent on CEO's intuition. Entrerprenership nature and at the same time strong intrapreneurship of the central figure in the company are greatly influencing decision making in NPD innovation in the company. The company applied the integrated strategy to allocated more resouces in marketing and promotional innovation than the NPD innovation itself. The strategy was choosen in order to win competition in the related market. Through the new products, the company share values to the customers by promoting issues such as 'the pride of being part of Indonesian, nationalism, local wisdom, traditional art and culture, diversity, environtment, peace, humanity, healthy lifestyle, and Indonesia's spectacular panoramas.

In spite of tight competition in the next 5-10 years, the company should be able to formulate a more formal guidelines and customized for a more comprehensive product development. The customized system can be applied to accomodate the principles of NPD process: flexibility, fluidity, focus (priority and portfolio management), facilitation and forever green (always to regenerate and repair) to support innovation in the company. However, considering the existing size of the company, a cross functional team was very limited, while too many NPD projects were conducted. A formal guidelines is also required to guide the process more efficient and effective. The company is also expected to also provide opportunities to more employees participation in the NPD innovation process through bottom-up approach. .

\section{References}

Arnzten, A.B. \&Voransachai, L. (2008). Aligning knowledge process and innovation management capability in a global business. Communication of the IBIMA, 6, 130-135.

Brethauer, Dale .(2002) New Product Development and Delivery.Ensuring Successful Products Through Integrated Process Management, New York: American Management Association (AMACOM).

Broring, S. Cloutier, L.M., \& Leker, J. (2006). The front end of innovation in an area of industry. $R$ and $D$ Management Journal, 36(5), 487-498.

Bullinger, H. ,J. Warschat, D. Fischer. (2000). Rapid product development-an overview. Computer in Industry 42: 99-108

Cooper, R.G. (2001) Winning at New products. Accelerating the Process from Idea to Launch, New York: Basic Book .

Ekstedt, M., Narcisa J., Leonel P., Enrique S.M., Norman V. (2005). Industrial information and control systems, KTH -Rroyal an organization-wide approach for assessing strategic business and IT Alignment. PICMET

Ganguly, K.,Satyabrata D. and P.K.Bandyopadhyay. (2013). Compressed new product development cycle \& its impact on outsourcing decisions in auto component industry. International Journal of Managing Value and Supply Chains (IJMVSC), 4(2), 25-37.

Gmelin H., S. Seuring (2014a) Determinants of sustainable new product development. Journal of Cleaner Production 69: 1-9.

Gmelin H., S. Seuring (2014b). Achieving sustainable new product development by integrating product lifecycle management capabilities. Int. J. Production Economics 154: 166-177.

Felekoglu, B., Anja M.M., James M. (2013) Interaction in new product development: How the nature of the 
NPD process influences interaction between teams and management. Journal of Engineering and Technology Management 30, 384-401.

Helmi, R.L (2015).Mengelola Inovasi Bidang Pangan Fungsional. Dalam: Diah AJ, editor . Peluang Adopsi Inovasi Berbasis Data Paten di Bidang Pangan Fungsional . Jakarta:LIPI Press.

Iqbal, M., Rasli A,,Heng, L.H, Ali, M.B.,Hassan, I. \& Jolaee, A. (2011). Academic staff knowledge sharing intentions and university innovation capability. African Journal of Business Management, 5(27),110511059.

Kohne, H.L \& Sawyer, A. (2018). Process innovation: requirements and opportunities. European Journal of Management Issues, 26 (1-2), 22-28

Langerak, F. (2010) Accelerated product development. In Wiley International Encyclopedia of Marketing Jagdish N. Sheth and Naresh K. Malhotra: John Wiley \& Sons Ltd

Lin, H. (2007). Knowledge sharing and firm innovation capability: an empirical study. International Journal of Manpower, 28(3/4):315-332.

Lunvall, B. \& Nielsen, P. (2007).Knowledge management and innovation performance. International Journal of Manpower, 28(3/4), 207-223.

Mattews, J. \& Manley. K. (2009). Enhancing Research and Development: Designing Collaborative Environments for Innovation. Queensland University of Technology.

Nonaka \& Takeuchi (1995). The Knowledge-Creating Company . How Japanese Companies Create the Dynamic of Innovation. New York: Oxford University Press

Stošić B. \& Radul M. (2014).Possibilities of Opening Up the Stage-Gate Model. Romanian Statistical Review, 4:41-53.

Trott, P. (2005) Innovation Management and New Product Development 3rd edition. London: Prentice Hall, Pearson Education.

Pratama., W.P. (2018). Industri Minuman untuk Kesehatan Bakal Berkembang, Ini Alasannya.

https://ekonomi.bisnis.com/read/20181025/257/853355/industri-minuman-untuk-kesehatan-bakal-berkembangini-alasannya. Accessed on August, 30th 2019. 